\title{
FOREWORD
}

\section{David Der-wei Wang}

The Rouge of the North $\left(19^{67}\right)$ is the last of the three novels written in English by Eileen Chang (1920-95). Chang's two earlier English novels, The Rice-Sprout Song (1955) and Naked Earth (1957), were written during her sojourn in Hong Kong from $195^{2}$ to 1955 , as part of an anti-Communist literary campaign sponsored by the United States Information Service. For all their compassionate inquiry into human frailty in an era of moral fanaticism, the two novels flaunt politics in ways Chang would not have chosen had she had any choice. Chang came to the United States in 1955, hoping to restart her career as a writer of English fiction, and The Rouge of the North came as the result of a long period of work towards that goal. Compared with the two earlier works, The Rouge of the North exhibits many more of the characteristics that made Chang the most popular writer in Shanghai during the 1940s. This is a novel not about national politics but about politics as a daily practice of life. It does not have the usual revolutionary "obsession with China," to use C. T. Hsia's term; ${ }^{1}$ rather it probes the reactionary meaning of all such Chinese obsessiveness.

The story of The Rouge of the North revolves around the life of a woman named Yindi, from her coquettish youth to her shrewish and malevolent old age. Alongside Yindi's degeneration one sees the gradual breakdown of an old aristocratic family which Yindi marries into, against a backdrop of Chinese historical turmoil from the fall of the Qing dynasty to the last years of the Second Sino-Japanese War. Chang details the predicament of an old-fashioned household in a changing time, with moral and psychological vii 
consequences that amount to a macabre spectacle. Yindi's life is ruined by the stale environment which, ironically enough, she herself chooses. By agreeing to an arrangedmarriage proposal from a richer family, she had intended to exchange her beauty and youth for a more affluent, respectable life, and when she finds out that her husband is a blind, puny invalid and his household a feudal dungeon, it is too late. After years of bitter experiences, Yindi is seen at the end of the novel as a rancorous widow, standing watch over her only son, whom she has totally depraved, in a tomblike house enshrouded with opium smoke.

If this plot sounds familiar to readers of Chang's earlier works, it is because except for minor changes in characterization and episodes, the novel derives from Chang's novella Finsuo $\ddot{j}$ (The Golden Cangue, 1943). The novella was very well received, and Chang later translated it into English under the title The Golden Cangue. Similarly in the 1960 , when Chang was working on The Rouge of the North, she derived its Chinese counterpart, entitled Yuan-nü (Embittered woman). Rouge was published by the Cassell Company of London in 1967 , when Yuan-nü had already been serialized for a year in literary media in Hong Kong and Taiwan. ${ }^{2}$ A bilingual writer, Chang enjoyed a reputation of being able to rewrite or translate her Chinese works into English or vice ver $s a^{3}{ }^{3}$ but no other translingual practice engaged her so much as The Rouge of the North (or its ancestor, The Golden Cangue). Thus, over a span of twenty-four years, in two languages, Chang wrote this story four times.

The year 1967 was the turning point of the last part of Chang's life. In that fall, her second husband, Ferdinand Reyher $\left(1897^{-1967)}\right.$, died after a long illness in Cambridge, Massachusetts, where she was writer-in-residence at Radcliffe College. Since their marriage in 1956 , the couple had had a close but financially unstable relationship, and more viii 
often than not Chang became the major source of family income, taking on chores such as script writer for the Voice of America and for a Hong Kong movie studio. Chang never ceased creative activity, however. After the disappointing outcome of the first two attempts, her entry into the English and American literary market had become all the more urgent; publication of The Rouge of the North was therefore a crucial step in her career.

But the novel came out at an emotionally difficult time in her life, and worse, it was received coldly by both reviewers and general readers. Ironically, the Chinese version of the novel was warmly welcomed in Hong Kong and Taiwan, and in overseas Chinese communities, thereby rekindling "Eileen Chang fever" among Chinese readers for years to come. Chang subsequently gave up hope of becoming a professional writer of English and turned instead to work on several other Chinese projects. In 1969, through friends' arrangements, she left the East Coast for good, to become a researcher at the Center for Chinese Studies of the University of California at Berkeley. Two years later she had lost this position, and she moved to Los Angeles, where she began the final twenty-five years of an increasingly reclusive life.

From Chinese to English, from The Golden Cangue to The Rouge of the North, why did Eileen Chang keep writing the same story? Circumstantial factors may provide some explanations. After two disappointing efforts, Chang needed a novel to bring her the much-expected breakthrough. To that end a story such as The Golden Cangue seemed to contain the most promising ingredients: a woman protagonist, an orientalist allure, and a family-saga structure. More important, looking back at the success of The Golden Cangue among Chinese readers twenty years before, Chang must 
have concluded that a work of a similar nature should also appeal to her prospective Western audience. I even suspect that C. T. Hsia's critical appraisal may have confirmed Chang's decision. In his History of Modern Chinese Fiction (1961), Hsia took a then most unorthodox stance by celebrating Chang as a major writer of modern Chinese fiction up to 1949. His chapter on her centers upon a favorable analysis of The Golden Cangue. ${ }^{4}$

Beyond these contextual surmises, nevertheless, there must be something else that drove Chang to repeat herself, something more keenly felt that made the rewrite an artistic necessity. One can guess that years after leaving Shanghai, the ultimate source of her inspiration, Chang might have wanted to rescue her dimming memories of the beloved city by continually naming it. Thus Shanghai's meandering alleys, crowded, dilapidated bungalows, hybrid fashions, night cries of snack vendors, mixed smells of sesame oil, medicinal herbs, and opium, its festivities and rituals, courtesan culture ... are fondly called up as the subtext of The Rouge of the North. Above all, Yindi's is a Shanghai woman's adventure; to write about her ups and downs is to recapitulate the changed morals and manners of the city during the first half of the twentieth century.

Or at a deeper, psychological level, one can draw on the Freudian model and view Chang's rewriting as a compulsive act that would overcome her own trauma by explaining it away. The four versions of The Rouge of the North (or The Golden Cangue) can be read as various accounts of her family romance, each revealing bits and pieces of a past from which Chang tried in vain to escape. The Yao family in The Rouge of the North, for example, easily reminds one of Chang's own, which enjoyed wealth and prestige in the late Qing days but underwent rapid decline after the founding of the Republic. Chang's father was a profligate consumed 
by opium, women, and memories of bygone family splendor. He led a life estranged from Chang's mother, a freespirited woman who found solace by traveling overseas. When the couple finally broke up, Chang and her brother were left in the custody of their father and new mother, an old-fashioned, peevish woman and opium addict. At the age of sixteen, after a quarrel with her stepmother, followed by her month-long imprisonment in her own room and a devastating attack of malaria, she ran away from home for good. For Chang, images such as the moribund household, dissipated male family members, absent mother, evil stepmother, and decayed aristocracy that fill The Golden Cangue and The Rouge of the North are not merely literary motifs; rather they are figures symptomatic of the uncanny "return of the repressed," continued linguistic approximations of an unspeakable trauma.

What concerns me here, however, is not the extent to which Chang has retrieved or revised her repressed memories through storytelling. Literature need not serve merely as reference to authorial turmoil. Instead of tracing out the apparent similarities between The Golden Cangue and The Rouge of the North and identifying in them the imprints of Chang's lived experience, I argue that the differences underlying the seemingly repetitive writings provide more clues to Chang's desire to retell her story. In other words, in her effort to reconstruct the master plot through various forms, Chang may also engage in a more subversive activity by proliferating and therefore undermining that master plot. The rewriting project becomes all the more intriguing when one considers the issue of language and translation. As if she could no longer trust her mother tongue, Chang seeks a substitute voice-in this case, English - in which to communicate. A foreign language was no more alien a medium than Chinese to transmit, or translate, her already alienated 
existence in the Chinese environment. Insofar as mimetic realism was the most important format of modern Chinese fiction, Chang's repetitive and bilingual project has offered a special perspective from which to view such premises as thematic and linguistic authenticity. They point to her unique stance as a woman writer as well as her philosophy of writing.

When The Golden Cangue was published, Chang was a single woman writer of twenty-four. The novella brought her unexpected acclaim from critics such as Xunyu (pseudonym of Fu Lei) and Hu Lancheng (1905-81), the flamboyant literatus and collaborator during the Japanese occupation, and to a large extent it led to her romance and eventual marriage with $\mathrm{Hu}$. A story about the transformation of a woman named Qiqiao from her frustrated youthful days to the moment when she has become a miserly widow and vampirish mother, the novella excels in its unsentimental exposé of women's fate in the traditional family system and in its intricate narrative skill, which superbly fulfills the standards of high realism. Next to Lu Xun's Madman in "The Diary of a Madman," Qiqiao must be the most memorable "madwoman" in modern Chinese fiction testifying to (what $\mathrm{Lu}$ Xun calls) the cannibalism of Chinese society. Suffice it for C. T. Hsia to say that "The Golden Cangue [is] the greatest novelette in the history of Chinese literature." 5

While The Rouge of the North derives its story from The Golden Cangue, one finds interesting differences in the way Eileen Chang relates the plotline. Although she is a woman just as deeply disappointed by life as Qiqiao, Yindi appears a milder and therefore arguably more mediocre version of her counterpart. Where The Golden Cangue with its novella format highlights only the moments crucial to Qiqiao's life, The Rouge of the North traces every twist and turn of Yindi's 
moral and psychological degeneration. The result is a prolonged account filled with details, details which discharge the intensity of the original story and as such make the characters fuller and yet less compelling creatures. In The Golden Cangue, for example, Qiqiao's desire for her brotherin-law, Third Master, is only suggested in a scene of mutual flirtation. In The Rouge of the North, one learns how Yindi once sang a ballad to Third Master in the dark at night, had a frustrated rendezvous with him at a Buddhist temple, and tried to kill herself afterward out of shame and fear. Qiqiao later schemes to ruin her son's and daughter's marriages, and toward the end of the novella she is seen confined to her opium couch, all by herself, awakening only momentarily to the horror of her perverted existence. Yindi has only one son. Like Qiqiao, she manipulates her son's life and is responsible for his wife's death, which is followed by an irony: she ends up having to live with her son's vulgar concubine and a group of totally unlikable grandchildren.

C. T. Hsia's analysis of Qiqiao would sound equally persuasive if applied to Yindi, a woman embittered to the point of perversion by her surroundings. But critics have pointed out that Yindi is lacking in the kind of vengeful determination and manic energy that make Qiqiao the most villainous mother in modern Chinese literature. ${ }^{6}$ For a story whose power depends on its protagonist's irreconcilable resentment of the world and people around her, Yindi may indeed appear to be a less successful creation. Eileen Chang, however, would have argued differently, and her reasoning might very well have been based on her polemical concept of realism. Take a look at her famous statement in "My Own Writing," written in the 1940s:"

There aren't many people around who are either enlightened or perverse to an extreme. This is a trou- 
bled era that does not allow for any easy enlightenment. In these years people have just gone on living and even though insanity is insanity, there are limits. So in my stories, with the exception of Cao Qiqiao in The Golden Cangue, none of the characters are extreme.... They have no tragedy, just desolation.

Chang wrote these remarks in response to charges that her works were not realistic enough to reflect the ethos of the time. As the mainstream discourse of the post-May Fourth movement, realism by the $194^{\circ}$ s had become a codified dogma informed by various ideological and emotive imperatives. As Chang intimates in the above quotation, this realist discourse disguises both a high-strung sentimentality and a radically heroic call to arms. For Chang, realism lies instead in the territory where heroism is susceptible to compromise and revolutionary postures are struck for private, often trivial motives. Quite contrary to the common wisdom, she contends that realism can best exert its power by depicting not extremities but expediencies, not life as tragedy but life as desolation.

Qiqiao of The Golden Cangue harbors an extraordinary rage and delusion and shows no qualms inflicting these upon her closest family members; she induces our pity and fear, in the tragic vein, in that her fall shocks us to an understanding of her pain and vengefulness. A powerful figure she may be, nevertheless her portrait is one Chang's aesthetics of desolation would not endorse. It is Yindi, with her entanglement in the redundancy of life and her insuffcient attempts in protest against that redundancy, who brings forward the vulnerability and mediocrity in us, flaws which are all too human. Such a view may raise some readers' eyebrows, and the debate over the The Golden Cangue versus The Rouge of the North will continue in the foreseeable xiv 
future. My point is that between Qiqiao's malice and Yindi's bitterness there exists a whole range of emotional capacities, and that it took Chang more than two decades to transform her Qiqiao into Yindi, or to turn a tragic monster into a desolate woman.

At a time when most Chinese writers engaged in a resolute rendition of typical characters and epic subjects, Chang's preference for the desolate aspect of life already bespoke a personal agenda. Her realistic project did not stop here, however. Insofar as modern Chinese realism was based on a mandate to reflect-duplicate without altering-the real, Chang's effort to double, nay, to quadruple, the reflection came as an intriguing critique of the conventionally simplified view. In view of her vivid assemblage of detail drawn from all aspects of life, one might easily conclude that Chang's rewriting of the prototype of Qiqiao/Yindi amounted ultimately to more fully re-representing the same reality, or to reflections of one reality from different distances and angles. This view would tend to overlook the deliberately unrealistic aspect of her project. Consider Chang's own observation: ${ }^{8}$

In this era old things break apart and new ones emerge. But until the era reaches its apex, earth-shattering events will be the exception. People only sense, to the point of terror, that things are not quite right in all aspects of their daily lives.... In order to prove their existence and grasp something real and quite elemental, they have no choice but to draw from their ancient memories for help, memories lived by all humanity in all eras.

In other words, when history has already crumbled and reality faltered, realism defined consensually has lost its legiti- 
macy. In quest of alternatives, a conscientious writer can best express herself not by confronting or even prescribing actualities but by taking shelter in "ancient memories." Instead of proclaiming the irreversibility of time or the authenticity of action, as most of her peers did, Chang turned to involuntary memories, and willed repetitions prevail over reflections of empirical reality.

Gilles Deleuze once differentiated two levels of literary representation: "The first exactly defines the world of copies or of representations; it establishes the world as icon. The second, against the first, defines the world of simulacra. It presents the world as phantasm."9 Most readers will have no difficulty appreciating Eileen Chang's realism at the first, mimetic level; all her works bear witness to her talent in recapitulating the world in its utmost intricacy. But I argue that Chang distinguishes herself more for her realism at the second level. She shows that the world we so confidently inhabit may already be a phantasmagoric existence, devoid of any solid meaning, and that any textual representation of it ends up becoming part of a chain of ghostly reflections. Her favorite subjects always involve ghostlike figures inhabiting a reality which no longer is, or never was, true. More important, her style betrays a futile inquisition of the immemorial and the unrepresentable, all the while impressing with its spectacular grappling with sensory, tangible data. Thus, in her own words, "a strange feeling toward surrounding reality emerges, a suspicion that this is an absurd, ancient world, dark and shadowy, and yet bright and clear. Between memory and reality an awkward disharmony frequently arises, and because of this a disruption-at once heavy and light-and a struggle-serious, yet still nameless-are produced."10

It is in this light that Chang's rewriting of The Golden Cangue and The Rouge of the North came as a truly fascinatxvi 
ing project. The two works, together with their Chinese versions, beget each other's causes and effects, and as such they break open multiple entry points onto the real within the mimetic closure of representationism. In Walter Benjamin's words, "the important thing for the remembering author is not what he experienced, but the weaving of his memory." ${ }^{11}$ While the majority of Chinese writers from the $194^{\text {os }}$ to the 196 os were eager to carve out the lucid image of their time and its single future, to have their say about what reality is and will be, Eileen Chang took a wholly different direction, by returning to her past and by letting it repeat itself, unwoven and rewoven in memory. Instead of the bright and clear worlds of May Fourth enlightenment and revolution, her works describe the dark realms of memory and desire, realms where ghostly interchangeability and duplicity prevail. Unsurprisingly, her philosophy of the real had to be acted out as a lifelong task. In the mid-196os, when Chang tried again to tell the story of The Golden Cangue two decades after its first publication, she had aligned herself with such masters of recapitulation as Tanizaki Junichiro of The Bridge of Dreams, Marcel Proust of Remembrance of Things Past and, above all, Cao Xueqin of The Dream of the Red Chamber.

$$
\text { o }
$$

For all her concern about an age in transformation and a city-Shanghai-in decline, Eileen Chang makes woman and her status in the Chinese family system the central issue of The Rouge of the North. Yindi appears at the first as a saucy and resourceful girl, determined against all odds to seek her own marriage. Her parents already dead, she lives with her brother's family, which makes a living selling sesame oil. Yindi falls in love with Young Liu, an apprentice of the herbal medicine store next door, but she is wary of the predictable, poor life ahead of her were she to marry him. 
Thus when approached by the go-between on behalf of the rich and powerful Yaos, she agrees to the marriage proposal as the result of pragmatic considerations. Little does she know that her future husband is a blind, puny invalid, one of the living dead, and that the Yaos' household is stifling and decadent. The rest of the story traces the consequences of Yindi's decision: her humiliating position among the inlaws, her sexual frustration with her husband, her increasingly haughty manner born of self-defense, her fruitless affair with her brother-in-law, Third Master, her widowhood, and her last metamorphosis as miserly tyrant.

For feminist readers, The Rouge of the North may appear to be a conservative novel, one which exposes the misery of Chinese women but fails to provide the necessary enlightening passages. Compared with contemporary women writers such as Ding Ling (1907-86) and Xiao Hong $\left(19^{1} 1-4^{2}\right)$, Chang shows little intent either to record or to imagine revolutionary alternatives for Chinese women. Under Chang's treatment, Yindi would at first glance hardly seem designed to win sympathy. Motivated by pragmatic considerations, Yindi chooses to bow to convention midway through her decision to fight for her right to choose. Worse, as if she had not suffered enough on her own, she later emerges as the most stubborn defender of the old customs and sees to their implementation in her son's and daughter-in-law's life. She subjects herself to a system which first victimizes her and then converts her to victimizer. (To borrow Lu Xun's popular metaphor, after being served up at the cannibalistic banquet of Chinese feudalism, Yindi develops her own taste for human flesh.)

As a character who fails to exit the vicious circle imposed on Chinese women, Yindi may seem best taken as a negative example, illustrating the triumph of a malecentered social machine. A closer reading, nevertheless, in- 
duces a very different interpretation. Chang may not be a feminist writer informed by "correct" consciousness, but throughout The Rouge of the North she never stops contemplating Chinese women's predicaments and the possible ways out. For Chang, Yindi's tragedy lies not in her acceptance of her destiny but rather in her wish to transgress its boundaries. Born with a shrewd, snobbish nature, she tries hard to transcend her milieu, and when she accepts the Yao family's proposal, she demonstrates the kind of selfexpectation and unscrupulousness found in many a naturalist heroine. But as Chang would have it, Yindi calculates to no avail before spinning the treacherous Wheel of Fortune; her option of marrying either her beloved Young Liu or the invalid son of the Yaos proves to be a false one. Although in her old age she has every reason to regret the waste of her life, Yindi is aware nonetheless that the roads not taken led only to other forms of frustration and death.

Critics can call Yindi a coward, who quickly reconciles herself to society once she finds herself caught in its snares. Chang would not have thought so. While she might well salute those heroines who break the bondage of society and start a life anew-just as she did-Chang knew only too well that most Chinese women of her time had neither the skills nor the resources to change their own destinies. These women deserve a voice on their behalf. One can imagine that when Yindi joins cannibalistic male feudalist society, she is undergoing as painful a rite of passage as a woman who flagrantly exits from it in search of her modern selfhood; more so, if one recalls that she did not initially belong to a social stratum that could underwrite such a quest. Yindi's bitter success thus leads us to ponder the question: If it is not easy to become the New Woman in a traditional society, wouldn't it be at least equally trying to be a (self-imposed) traditional woman in a New Age? Yindi 
remains a last guardian of the Chinese family tradition when all her relatives have given up its already dated manners and rituals. Her eccentric conservatism partakes of a fanatic fervor which, with a deft reversal of the direction of history, would easily be recognized as radicalism. Not unlike certain female characters in late Ming storyteller tales, Yindi attains an unlikely existential prominence in a historically suffocating environment, not by defying its already obsolete values but by obeying them to the extreme. ${ }^{12}$

From Yindi's story one extracts an important feminist notion which we may attribute to Eileen Chang. Though less utopian than some of those recently in fashion, this notion can contribute to the debate on how to interpret the historical evidence of female victimization in view of modern women's desire for female agency. Chang of course means to make Yindi showcase Chinese women's degradation in a premodern world. But instead of promoting an across-the-board female victimology, she contends that such a subjugated position does not necessarily translate into virtue. Innocent suffering does not constitute grounds for sanctification. Yindi's story implies that whenever they are given a chance, women can prove to be just as cunning and conspiratorial as men. Women are as capable of oppression as men are, including the oppression of their own kind. There could be no feudal victimization without feudal women to prepare for, control, and administer most of it. In Chang's own words, from her essay "On Women," "thanks to the confined space allowed to their activities, perfect women can appear more perfect than perfect men, while villainous women can be more thoroughly villainous than villainous men."13

One could retort that a woman like Yindi after all is coopted by male power and that she pays a far greater price for what she becomes. Chang could not have agreed 
more, while perhaps adding that precisely because she understands women's disadvantageous situation so well, she has to pay due respect to the ways by which they survive male coercion, however infamously. The Yao family is headed by the dowager-empress-like Madame Yao. Witness the way she manipulates her sons in the name of the malecentered domestic ideology, and one realizes that Yindi is but a derivative version of the old matriarch. Through their collusion with men, women appropriate men's power and turn it against them. In other words, Yindi's story calls attention to the fact that unless women could be no less selfish, cruel, and energetic than men, there would not have been a chance for (some of) them to turn the tables and oppress their male oppressors, to say nothing of someday overturning all the institutions of male oppression. Rouge may appall us with Yindi's degradation, but the flip side of it indicates the fiendish persistence of women's power, which could be turned to other ends, in other societies, if not in Yindi's.

Chang's logic, to be sure, takes on a Machiavellian dimension and thus does not fit the consensual scenario ascribed to Chinese women of bygone days. For post-May Fourth humanists as for contemporary fundamentalist feminism, Chang's women characters are neither weak nor helpless enough to symbolize their abused status under traditional circumstances. But this is exactly the point Chang tries to make over and again in her fiction and essays: her women are earthy unscrupulous survivors, not honorable tokens. ${ }^{14}$ In the battle between men and women, nobody leaves with clean hands. Alongside Yindi's dehumanization, all the male characters also undergo their own cycles of failure. Yindi's husband is a human skeleton and dies young; her brother-in-law, Third Master, ends up living off two prostitutes-turned-concubines; Yindi's sole son appears to 
be totally demoralized by the novel's close, thanks to his mother's fervent moral teaching. By portraying Yindi as both vulnerable and dangerous, both a victim and a victimizer, Eileen Chang has complicated the terms of gender politics and celebrated female power in her own cynically honest way.

$$
\text { \% }
$$

Granting the contributions to the debate, one recognizes nonetheless that Yindi remains an unhappy woman and that this emotive state constitutes the most poignant aspect of Eileen Chang's inquiry into a psychology of women. The title of the Chinese version of The Rouge of the North, Yuan-nü, is in many ways more suggestive of Yindi's state. The Chinese character yuan denotes such meanings as "embittered," "sullen," and "rancorous;" when used to describe women, it refers to a major trope in classical Chinese poetic invocations of the feminine. Yindi's is thus not one woman's story; rather it reminds one of thousands of Chinese women who have been so deprived by their time and environment as to wither away in chronic distress. In contrast to masculine rage or wrath, Chang sees in women's simmering embitterment a menacing force, which often threatens their own well-being before it endangers society as a whole. Throughout her life Yindi tries to seek outlets for her deep-seated frustration or yuan-by marrying a rich husband, by her rendezvous with her brother-in-law, by fighting for family inheritance, by demoralizing her own son, even by trying to commit suicide. But to her chagrin (or yuan?) each of these attempts turns to have been another empty promise replacing the previous one, and her life amounts to nothing but a bitter spiral, closed in upon itself.

Critics in the vein of psychoanalysis cannot find a better case than Yindi's to address problems from depression to hysteria, from ressentiment to melancholy. Of all the synxxii 
dromes readily to be identified, abjection is perhaps the one worthiest of consideration. Coined by Julia Kristeva, the term abjection refers to signs of repugnance as reactions to an inability to transcend the base associations of the corporeal such as food, waste, and gendered difference. ${ }^{15}$ In contrast to the rational distinctions formed by (patriarchal) language and sign systems, the abject focuses attention on the "thresholds," which are manifested, among other ways, in those bodily orifices blurring the distinction between the inside and the outside, attraction and repulsion, Eros and Thanatos. While one could pursue Kristeva's theory further, my concern here is that abjection describes a feminine dialogue between desire and loss that resonates most intensely in "the ambiguous and the transgressive."16 Yindi, I argue, occupies just such an ambiguous and transgressive position in coming to grips with her sexual and social identity. She wants to find her own man and yet is rewarded with a living dead man; she is tom by adulterous desire in her younger days, only to settle into her widowed life with formidable stoicism; she seeks to end her life in the middle of the novel, but outlives all the other major characters. Shuttling between the possibilities and impossibilities of her life, Yindi is never what she appears or wants to be; her transgressive desire continually throws her back into the closure of repetition.

But where Yindi eventually closes herself to the world in despair, Eileen Chang understands that something has happened. Where Yindi fails to articulate her pain, Chang is capable of naming at least the unspeakability of the pain. "Abjection appears," as one critic puts it, "where boundaries are traversed and unity punctured so that the resultant breach threatens to widen and overtake the whole."17 This leads us to reexamine the scene which opens and closes the novel. In that scene, the teenage Yindi had been about to xxiii 
go to bed one night when she was disturbed by a repeated knocking at her door, with a man calling, "Miss! Miss!" Who was this man? What was happening outside the house in the darkness of night? Should she open the door? Almost unprepared, Yindi is pushed to the threshold of her life, so to speak, and she has to decide how to face up to the vehement pounding on her door. The door-pounding scene recurs at the end of the novel, in Yindi's remembrance of things past. The return, or repetition, of the youthful experience functions like a belated epiphany to Yindi, which sheds mysterious light on her life, though only in retrospect. Chang might have suggested that it bespeaks more emphatically the elusiveness of Meaning of any kind. Despite her eventful life, what happens to Yindi is really a repetition of her precursors' fate. The pounding at the beginning becomes an empty promise, with hollow echoes resounding throughout the narrative.

By repeatedly writing about a woman's abject experience in different forms and languages, Chang seems to have reenacted that door-pounding scene, trying to force open Yindi's world and to rethink the choices such women once had to make. And in view of Chang's own ambivalent response to Yindi's eventual fate, one wonders if she has projected her own drama of transgression and repetition. It is in this regard that Kristeva's interest in the linguistic underpinning of abjection theory lends special help. If language is that which is predetermined by the patriarchal symbolic order, the feminine presents itself as an amorphous semiotic force coming from outside the male order. This force continuously releases disruptive impulses into the symbolic while risking the fate of being expelled, which results in abjection. Women's writing in this interpretation is an unstable and provisional process, one that requires continued renegotiation, and reinscription, in its dialogue with the symbolic. 
This tension is best dramatized in the climactic scene of The Rouge of the North, Yindi's liaison with Third Master. Yindi has followed the Yao family to a Buddhist temple in commemorative rites for the dead Master Yao. With her newborn baby she wanders into a courtyard where a huge iron urn stands:

She wandered across the courtyard around the huge iron incense pot on its stone pedestal. Row upon row of names were engraved on it in small fine characters, donors who had this incense pot made, "Mrs Chan, née Wong; Mrs Wu, née Chow; Mrs Hsu, née Li; Mrs Wu, née He; Mrs Fung, née Chan ..." The purposely characterless names became a bit depressing seen en masse. These were the women who went in for good works pinning their hopes on the next incarnation. She had the feeling that if she looked more closely she would find her own name there, cast in iron. Maybe she had come across it without recognizing it.

This is a crucial scene because it is followed by the sudden appearance of Third Master. Should Yindi transgress the conventional boundary of feminine virtue by succumbing to the seduction of her brother-in-law? Or should she follow the model of those women who led a pious, decent life and let their names be molded en masse into the iron incense pot? Yindi chooses the first option. She follows Third Master to a side temple and is ready to give in, leaving her baby crying on a prayer mat. But Third Master stops right after he has aroused Yindi; the sexual encounter she has so dreamed of never comes true. Frustrated and shamed by the rendezvous, Yindi later tries to hang herself; her rescuer is the last person she wants to live for, her husband.

One can imagine that behind every small inscription of a 
name on the iron incense pot, there is a story about a woman's embittered life; and for every woman whose name is being remembered there are hundreds of others who have been completely forgotten. Even the select few honored are known only by the names of their husbands. When she looks at the inscriptions and almost finds her own name among them, Yindi seems to have foreseen her own fate. But what follows this scene drastically undercuts the sullen implication of the inscriptions. I am referring not to Third Master's abortive seduction of Yindi, which is too obvious a contrast, but to the life Yindi leads long after the seduction. For all her youthful desire to break the law of virtuous womanhood, the aging Yindi becomes more and more pious and fanatical in her observance of established, patriarchal ideology. So it may not be surprising after all that she would yearn to be indirectly inscribed onto the monuments of patriarchal memory in return for obliterating herself on its behalf.

The way Eileen Chang describes Yindi's defiance of and spiteful conformity to conventional power thus may not be merely a deplorable case history. Rather it throws an ambiguous light, however unexpectedly, on the moral stature of those women who have had their names cast in iron. Insofar as their memories are all mere inscriptions, one wonders how many Yindis there must be among them, and, more poignant, how many others of them have carried on a complicitous relation with the male society that sanctioned them. The point is that these women may be neither naïve collaborators nor strong-willed martyrs living out malecentered fantasies. As Chang would have us surmise in the case of Yindi, perhaps their embittered life has trained them to seem and not to be: they may or may not have had a chaste and pious life, and yet they have managed to make men treat them as moral paragons. 
By emphasizing the other side of Yindi's life, a life which once would have been cast in iron as a barely visible patronym inscribed upon a temple pot, Eileen Chang exhibits the most polemical part of her idea of feminine power. And to a great extent her strategy of writing, or rewriting, resonates with this message. Alongside her descriptions of Yindi's (or Qiqiao's) adventure, she sought within the May Fourth realist discourse a voice of her own, a voice that turned the programmatic enunciations about nation, humanity, and revolution into something else: she has blurred the nation, making it appear as alienation, making humanity show itself as femininity, making revolution devolve into involution. Above all, in contrast to the metallic, isolated inscriptions on the incense pot, Chang's narrative does not take congealed shape but lets its meaning float almost invisibly on its surface, like currents upon the water. Significantly, Chang entitled her famous collection of essays Liuyan: literally, Floating Words.

$$
\text { \% }
$$

We can now return to our starting point and rethink the significance of remembrance and repetition, transgression and translation, in the cycle of Chang's The Golden Cangue and The Rouge of the North. Through retelling the story of Yindi and her previous incarnation, Qiqiao, Chang rearticulates her own scattered memories and those of other women. And through reproducing the ghostlike images of Chinese women in abjection, she undoes the singular, essential discourse of realism as a manmade myth. But more fascinating is the role translation plays in the cycle. Translation is a reiteration of the target language in a different medium, but it is at the same time a transgression, a violation as well as crossing of the linguistic boundary between what is decipherable and what is not.

Given Chang's background as a woman author with an xxvii 
old-fashioned father and a Westernized mother, a bilingual and cross-cultural education, and noncommittal political grounding, translation becomes as much a syndrome as a strategy in her coping with life-inevitably, a way of making a living. To translate means not so much to bring to light the hidden meaning of the original, or father, nation, and reality, as to acknowledge its obscure status, which is "dark and shadowy, and yet bright and clear." Shifting back and forth on linguistic, cultural, gender, and temporal territories, Chang is able to find that "between memory and reality an awkward disharmony frequently arises, and because of this a disruption-at once heavy and light-and a struggle-serious, yet still nameless - are produced." This is a realm where the four versions of The Golden Cangue and The Rouge of the North are put forward in contestation and thereby the fates of Chinese women are renegotiated.

In the $1960 s$, when a feminist from the vanguard like Ding Ling had been completely silenced and exiled to the far north, Eileen Chang, self-exiled thousands of miles away from China, still carried on. As Chinese Communist politics precipitated the Cultural Revolution (1966), with an ever louder call for the coming of the new China, Chang withdrew further back into the dark territory of old China. Through rewriting The Golden Cangue, she indulges in "ancient memories," "memories lived by all humanity in all eras." A novel like The Rouge of the North became for Chang a last imaginary refuge after she had already taken political asylum in the United States. And in a circuitous way the novel provides a critique of the dominant literary discourse in her own country. It is a repetition in subject, but it has more to say about the old roots of the new era; it is a work in her second language, but it more emphatically transmits, or translates, her ideas about femininity and creative writing, which remain unintelligible to ideologues and party- 
liners. Chang has always occupied a marginal position in literature, as in (gender) politics, and enjoyed that position with an ironic sense; but there must have been moments when she had to come to terms with her own state of abjection. The 1960s were years when Chang drifted with her bedridden husband from one place to another, dreaming her last dreams of becoming a professional writer of English fiction, while her hope of homecoming appeared ever dimmer. One wonders, as she later reread The Rouge of the North, how often she must have been bemused, or amused, by an uncanny thought - that fictional experience had infiltrated lived experience, and that she herself might finally have become the embittered woman.

\section{NOTES}

1. C. T. Hsia, "Obsession with China: The Moral Burden of Modern Chinese Fiction," in A History of Modern Chinese Fiction (New Haven: Yale University Press, 1961), pp. 533-54.

2. Originally titled Pink Tears, the draft of The Rouge of the North was finished perhaps as early as $195^{8}$, as the result of Chang's project at the MacDowell Colony in 1956. See Sima Xin (Stephen Cheng), Zhang Ailing yu Laiya (Eileen Chang and Reyher) (Taipei: Dadi chubanshe, 1996), pp. 81, 98, 126, 138.

3. The other two English novels by Chang, The Rice-Sprout Song and Naked Earth, also have Chinese versions, respectively titled Yangge and Chidi zhilian. After the publication of the Chinese edition of The Rouge of the North, Chang went ahead to rewrite her two novels published after the Chinese Communist takeover of mainland China, Shiba chun (Eighteen springs, 1949) and Xiao Ai (Little Ai, 1951). The reason for these rewritings lies in her displeasure with the pro-communist messages she was forced to insert in the originals.

4. Ibid., pp. 398-407. 
5. Ibid., $39^{8}$.

6. See, for example, Hu Xin, Zuihou de guizu (The last aristocrat) (Taipei: Guoji cun wenku, 1995), pp. 442-49.

7. Eileen Chang, "My Writing," trans. Wendy Larson, in Modern Chinese Literary Thought: Writings on Literature, 1893-1945, ed. Kirk Denton (Stanford: Stanford University Press, 1996), p. $43^{8}$.

8. Ibid.

9. Gilles Deleuze, Logique du sens, quoted from J. Hillis Miller, Fiction and Repetition (Cambridge, Mass.: Harvard University Press, 1982), p. 4.

10. Chang, "My Writing," p. 438.

11. Walter Benjamin, Illuminations, trans. Harry Zohn (New York: Schocken, 1969), p. 202.

12. For the conflict between individual commitment and social obligation in the Ming tales, see C. T. Hsia, "Society and Self in the Chinese Short Story," in The Classic Chinese Novel (New York: Columbia University Press, 1968), pp. 299-322.

13. Eileen Chang, "Tan nüren" (On women), in Liuyan (Floating words) (Taipei: Huangguan chubanshe, 1995), p. 88.

14. Ibid., pp. 86-91.

15. Julia Kristeva, Powers of Horror: An Essay on Abjection, trans. Leon S. Roudiez (New York: Columbia University Press, 1982), pp. 3-4.

16. Robert Newman, Transgressions of Reading (Durham: Duke University Press, 1993), p. $14^{1}$.

17. Ibid. 